\title{
Crowdworking, is it Beneficial in Destination Marketing?
}

\author{
(An Empirical Model in Tourism Destinations in Central Java)
}

\author{
Ratih Pratiwi*, Windi NR Wardhani, Retno Kusumaningrum \\ Management Program \\ Sultan Agung Islamic University \\ Semarang, Indonesia \\ *ratihpratiwi@std.unissula.ac.id
}

\begin{abstract}
With social media, the opportunities to promote the tourism destination are virtually endless. This exploratory research is examining crowd working as a new term in tourism that has not been investigated clearly and there is not much information available on it. The purpose of conducting this research is to develop more understanding about crowd working and provide answers to how crowdfunding benefit for tourism industry. This research conducted in Tourism destination in Central java. Data analysed with Amos statistical software. Crowd working in tourism industry defines as tourism destination that employ digital natives to tagging photographs and review their experience in visiting destination to their social media with tagging accounts, hashtag, communities and people. The result show that Crowd working and knowledge destination create an engagements of destination innovativeness to promote the destination trough social media content and this holds an enormous potential for the tourism industry. Knowledge destination is an amount or information own by a tourism destination resources about the destination. Having sufficient knowledge of tourist destinations will be able to increase the power of innovation so that the impact on marketing performance of tourism destinations will be increased. The power of innovation in a tourist destination greatly supports tourism marketing. Visitors always want to get new experiences and new stories in visiting a tourist destination. The ability of a destination to innovate following changes in existing tourist interests is needed in determining the marketing strategy of a tourist destination. In improving the marketing performance of tourist destinations can be improved through the role of crowd working with its indicators digital communities, social media promotion and networking; through the role of ownership of knowledge destinations and innovativeness. The existing literature on the crowdsourcing concept is relatively limited. Accordingly, this research adds a novel contribution to crowdsourcing literature and evaluates it and its impact as a source of the transformation of the tourism marketing.
\end{abstract}

Keywords-destination sustainable marketing, crowdworking, destination innovativeness, network factors, knowledge destination

\section{INTRODUCTION}

The industrial world 4.0 has force the organizations to have sufficient intelligence which is able to understand the complexity situation that occurs [1]; have a high adaptability to change [2], adequate thinking systems ability to see interaffection (closeness) in a larger system [3], high learning abilities [4], and highly innovativeness [5]. Basically every competing tourism destination has a desire to be superior to its competitors [6]. Destination management must apply a competitive strategy to develop its destination and to survive in the competition of the tourism service industry [7].

Tourism Business is a business that sells services. Cusumano and Kahl states that good customer service comes from a work environment that creates more value [8]. If services have been manifested in the nature, attitudes, habits, and daily behaviour then this can create more value for the organization as a result from the awareness and positive perceptions that exist within the company [9], synergizing the human resources strengths to provide the best service, providing maximum satisfaction for tourism service users [10]. The best service ideas are accustomed to flowing, developing, and evolving to create more value [11]. Value creation not only comes from innovation and creativity [12], but also from the right awareness and perception to collaborate with each other, synergize all the competencies and knowledge obtained to provide the best service [13].

As part of this transformation, tourism destination has increasingly been digitising their destination and making them accessible online to the public. This digitisation allows mobility states, and a new type of resources. Internet has become an important part in tourism, it postulates a positive relationship between Internet use and Tourism development. The internet technologies and social networks rapid development possibly enhance new ways of collaborative work mechanisms to emerge outsourcing and crowdsourcing became a powerful competitive strategy, reduce costs and spread the wings of tourism marketing.

Nowadays we can witness all sorts of businesses applying crowdsourcing mechanisms to their work and disrupting old business. The term "crowdsourcinge was defined as a mechanism through which firms can out-source work outside the firm to the individuals with the use of the internet. So many Researchers has their own perception and definitions of crowdsourcing Due to this diverse use of the term and different perspectives on the subject some activities that are being viewed as crowdsourcing by one researcher could not be seen as such by others.

Crowdsourcing is a distributed problem-solving production model that leverages the collective intelligence of online communities to serve specific organizational. Since this 
digitalization era, there are more ways to promote Tourism, a crowd working platform is providing a cheap, fast, highly responsive, and highly digitalized skill resources. They provide simple and communicate destination contents in the social media. Crowd workers should provide minimal but crucial information to those people with high Internet use or Internet addiction and those who love to surf the social media in getting information about the destination.

The success of the crowdsourcing platform largely depends on the participation of diverse and large crowd, so the most important thing in this platform was the worker's motivation. This article aimed to answer the big question of Tourism crowd working, the platform or task features which can facilitate their continuous engagement and its benefit in tourism industry.

\section{THEORETICAL FOUNDATION AND PREPOSITION DEVELOPMENT}

\section{A. Destination Sustainable Marketing}

Tourism marketing strategy can bring competitive advantage to a destination [14]. Scarce, valuable and unique human resources provide sustainable organization / competitive advantage, customer relations and systems that provide organizations with a position for ongoing competition [15]. Tourism marketing strategy is the basic thinking of creating a competitive strategy starts with how the business will be developed, what exactly is the goal and what policies will be needed to achieve that goal [16]. The leisure era turns the tourism destination marketing pattern from print media such as pamphlet, leaflet and books, into a testimony content in social media [17]. People attention now turns to exploring the overt and covert effect communication of discourses of sustainability on destination knowledge and experience in a visiting a tourism destination [6]. Tourism destination marketing in digital is often manifested in a YouTube or social media content which material consist of pleasure, experience, and satisfaction feeling of visiting a tourism destination [18].

Tourism destination marketing is the activity of a tourism destination in creating, communicating, delivering and exchanging all offers that have value to customers and by providing benefits and remaining accountable to society at large [17]. Tourism destination marketing management is all tourism destination activities in selecting target markets, obtaining, maintaining and growing selected customers by creating, delivering and communicating all offers that can satisfy customers also better than competitors [15]. Tourism marketing is a systematic and coordinated execution of tourism business policy whether private or state owned to achieve the optimal satisfaction of the identifiable costumers group needs and to achieve sustainability competitive advantage [18].

\section{B. Destination Innovativeness}

Destination innovativeness is the sustainable competitiveness of destination objects and tourist attractions in facing the competition and collaborating with similar objects to synergize strategies to attract the flow of tourist visits [13]. The tourism sector and industry must have uniqueness (differentiation) that is not owned by other regions and in order to establish this uniqueness, tourism marketers must have a high strategy and innovative power [19]. In tourism and hospital companies, innovation has proven to be more complex than general management [20]. Hjalager states that innovation in tourism occurs in the form of products / services, processes, managerial, marketing or institutional innovation [21]. There remains little doubt, however, about the relevance of innovation for the survival of tourism and hospital companies [21]. Previous researches have so far largely concentrated solely on exploring the innovative capabilities of tourist destination actors, without testing the effect on the importance of innovation as a competitive advantage [20].

The current paradigm shift in the meaning of innovation is compared with the development of product packaging, distribution, marketing and strategy [22]. There are many methods used to classify destination innovativeness but generally destination innovativeness revolves around the emphasis on object design and tourist attraction, market research, and advertising and promotion [23]. Destination Innovativeness is an important component in achieving sustainable excellence in the tourism sector for it reflects the important means of which organizations are able to capture new opportunities [9].

Destination Innovativeness reflects the tendency of a tourist destination in supporting new ideas, updates, experimentation, and creative processes that can produce new products, services, or playground developed [20]. Destination Innovativeness is defined as the willingness of tourism companies to innovate [24]. Destination Innovativeness is defined as a company's tendency to engage in and support new ideas, novelty, experiments, and creative processes which can create new products, services, or technological processes. Destination Innovativeness is generally measured by innovations that occur in tourism which covers tourism products / services, processes, managerial, marketing or innovation of tourist destinations [20].

It can be concluded that Destination Innovativeness is defined as the willingness of tourist destinations to engage in and support new ideas, novelty, experiments, and creative processes which can create new products, services, or new technological processes in existing playing fields. Destination Innovativeness is measured by indicators of assimilation, differentiation, inversion, and integration.

\section{Knowledge Destination}

Knowledge is a core component of innovation power. Because the knowledge that is embedded in individuals needs to be shared with other members so that it can help as a reference in problem-solving efforts. The tourism industry is an industry that requires tourism actors to have dynamic marketing capabilities and be able to update strategies by adjusting the development of tourist trends / interests, in the face of this highly volatile environment, knowledge sharing behaviour can voluntarily mobilize the knowledge base embedded in individuals to be able to innovate totally [13]. In this highly dynamic global market share, organizations can only become innovative when members are able to share their 
implicit knowledge and turn it into explicit knowledge for product and service innovation.

\section{Crowdworking}

Tourism nowadays has been considered as the most rapidly growing industry. It was seen as a vital tool for employment and wealth creation, social development, and foreign exchange earnings, which concurrently served to enhance cultural knowledge. Tourism also created socio-cultural and political networks, thereby it strengthening international relations too. Hospitality and tourism is one of the industries that is most affected by digital development. Transportation and accommodation companies are two of several industries in tourism industry which are utilize digital marketing techniques in their practices to engage communities and make sure their customers have the best possible away-from-home experience.

Social media has changed the tourism and hospitality industry marketing concept. Most tourists determine their travel plans based on reviews and comments on social media. Online media is become the most important key in building good reputation for a tourism destination, it has disrupted the traditional marketing model for tourism industry with social media, tourism industry players can utilize to build public awareness in increasing tourist behaviour, to enhance the tourist visit rate [25].

The disparital consumption of digital from what it used to be is nowadays people use it for making money. The use of mobile devices is on the rise; people can do anything with their phone. In tourism industry, people can use their gadget to book their airplane tickets and hotel rooms, choose tourism destination by the reviews on social media [25]. It can be said that the opportunities to promote the destination and its amenities online are virtually endless.

Crowd working is becoming increasingly popular. How the model works and why it could revolutionize the working world. While some people see it as a new phenomenon, others see is as an existing potential for a fundamental change in the tourism marketing strategy. Crowd working is the newest member of the set. The term crowdsourcing is a combination of crowd and outsourcing refers to websites that employ people to undertake mainly low-level repetitive tasks such as data entry, ranking URLs on Google, transcribing recordings or tagging photographs. Crowd working sites have been criticised for low pay, no security of employment and no appeal if a worker feels he has been unfairly treated.

Crowd working in tourism industry defines as tourism destination that employ famous people (selebgram, youtuber, blogger and public figures) to tagging photographs and review their experience in visiting destination. But nowadays not only famous people participate in crowd working, digital natives the youth fluent in using technology are take part in uploading their testimony and experience visiting a destination to their social media with tagging accounts, hashtag, communities and people.

The original idea behind crowdsourcing was voluntary collaboration but nowadays people participate for cash rewards called crowd workers. Crowd working is aimed to creating an engagements of social media and the digitally natives to promote the destination trough social media contents [25]. It's critical that the tourism industry players stay abreast of the latest trends and that they incorporate the most recent technology into the digital marketing strategy.

People believe that the best time of the year can be pricey not only financially; but searching for the best hotel, the nicest restaurant, the most exciting destinations can also be time consuming and stressful. In this flurry conditions people prefer to see the destination review to decide their visit. This digital marketing initiatives, being able to rely on experiences that others are glad to share with people on the Internet providing a recommendation for a restaurant, travel reports, photo series, and this holds an enormous potential for the tourism industry.

\section{RESEARCH METHODOLOGY}

\section{A. Sample}

The population of this study is 105 high priority tourism industry in Central Java Province. The sampling method used was census, data obtained were processed by Amos.

\section{B. Measurement of Variables}

The variables were measured with questionnaire by using Likert-scale with answer scale of 1 to 5. The scale represented the rating from 'strongly disagree' to 'strongly agree'. Table 1 shows the results of validity and reliability test and a loading factor value above 0.7 [26] and a minimum reliability value of 0.6 [27]. Therefore, it can be concluded that the instrument has the validity and reliability.

Destination knowledge was measured with indicator tourism trends, understand the destination history, knowing the destination well. Destination innovativeness was measured by assimilation, differentiation, inversion, and integration. Crowd working was measured with social media promotion, networking and digital communication. Sustainable marketing performance was measured with obtaining visitor, selecting target market, maintaining visitor rate, growing income.

The variables were measured with questionnaire by using Likert-scale with answer scale of 1 to 5. The scale represented the rating from 'strongly disagree' to 'strongly agree'. Table 1 shows the results of validity and reliability test and a loading factor value above 0.7 [26] and a minimum reliability value of 0.6 [27]. Therefore, it can be concluded that the instrument has the validity and reliability.

\section{Analitycal Result}

Based on the reliability test results, Table 2 shows that the four constructs, namely Destination Knowledge, Destination Innovation, Crowd working, Sustainability marketing performance are reliable. The statement is proven by the value of Construct Reliability of all variables are above 0.70 . Thus, the reliability test of all variables in this study can be accepted.

After conducting a confirmatory analysis on the forming indicators of latent variables, the next analysis is a full model Structural Equal Modelling (SEM) analysis. The results of data 
processing for the full SEM model analysis are presented as in figure 1.

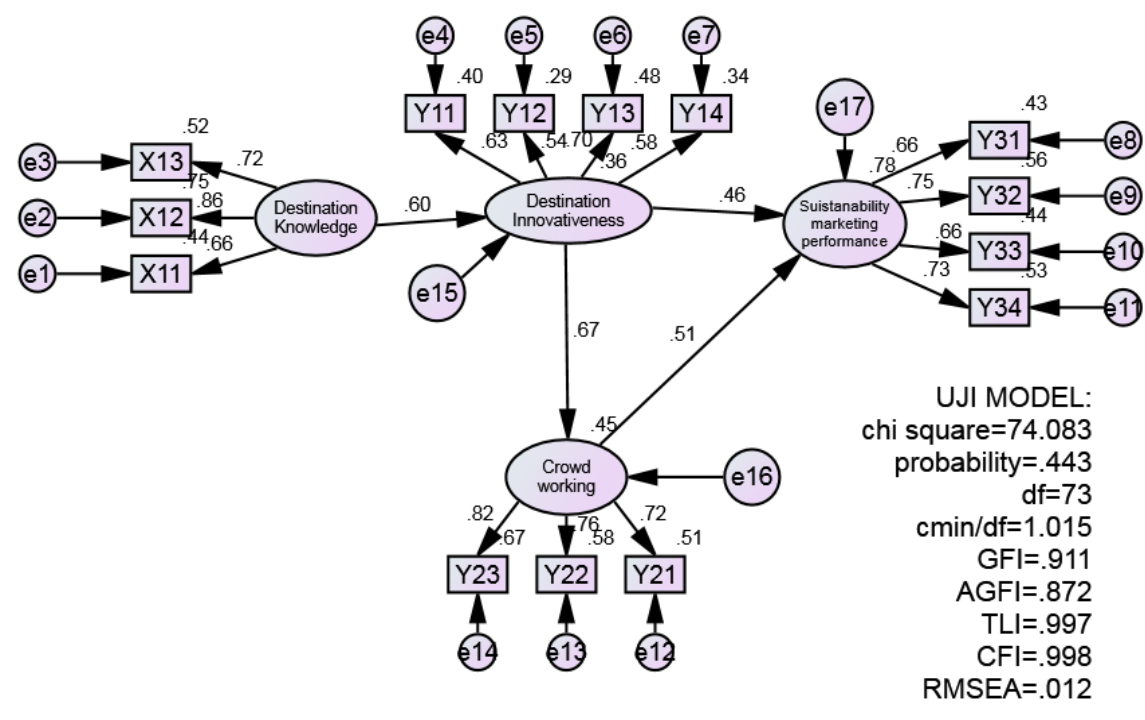

Fig. 1. Full SEM model analysis.

The results of the goodness of fit for the full model of SEM test in this research model can be presented in Table 1.

TABLE I. Testing Results of GoOdness of Fit FOR THE COMPLETE MODEL

\begin{tabular}{|l|l|l|l|}
\hline $\begin{array}{c}\text { Goodness of Fit } \\
\text { Index }\end{array}$ & Cut off Value & $\begin{array}{c}\text { Estimation } \\
\text { result }\end{array}$ & \multicolumn{1}{|c|}{$\begin{array}{c}\text { Model } \\
\text { Evaluation }\end{array}$} \\
\hline Chi-Square $(\mathrm{df}=73)$ & Small $(<93,95)$ & 74.083 & Fine \\
\hline Probability & 00,05 & 0.443 & Fine \\
\hline CMIN/DF & $\leq 2,00$ & 1.015 & Fine \\
\hline GFI & $\geq 0,90$ & 0.911 & Fine \\
\hline AGFI & $\geq 0,90$ & 0.872 & Marginal \\
\hline TLI & $\geq 0,95$ & 0.997 & Fine \\
\hline CFI & $\geq 0,95$ & 0.998 & Fine \\
\hline RMSEA & $\leq 0,08$ & 0.012 & Fine \\
\hline
\end{tabular}

TABLE II. INNER PATH MODEL COEFFICIENTS AND THEIR SIGNIFICANCE

\begin{tabular}{|c|c|c|c|c|c|c|}
\hline No & Affecting Variable & $\begin{array}{ll}\text { Affected } \\
\text { Variable }\end{array}$ & $\begin{array}{c}\text { Standard } \\
\text { Coefficient }\end{array}$ & C.R & $\mathbf{P}$ & The effect \\
\hline 1 & Destination Knowledge (X1) & Destination Innovativeness (Y1) & 0,600 & 4.222 & 0.000 & significant \\
\hline 2 & Destination Innovativeness (Y1) & Crowd working(Y2) & 0,671 & 4.115 & 0.000 & significant \\
\hline 3 & Destination Innovativeness (Y1) & Sustainability marketing performance (Y3) & 0,457 & 2.663 & 0.008 & significant \\
\hline 4 & Crowd working(Y2) & Sustainability marketing performance (Y3) & 0,507 & 3.223 & 0.001 & significant \\
\hline
\end{tabular}

Based on the results of testing the overall model in table 2, the further mathematical model equation can be written in the form of Structural Equation Model (SEM) as follows:

$$
\begin{array}{ll}
\mathrm{Y}_{1}=0,600 \mathrm{X}_{1}+\varsigma_{1} & \mathrm{R}^{2}=0,360(1) \\
\mathrm{Y}_{2}=0,671 \mathrm{Y}_{1}+\varsigma_{2} & \mathrm{R}^{2}=0,450(2)
\end{array}
$$

Results in Table 1 indicate that this model is suitable according to the data or Fit on the available data. Chi-square index, probability, CFI, TLI, GFI, CMINDF and RMSEA are in the range of expected values, which are included in either category. In the AGFI index, the results obtained are not good, but the value is close to the cut-off value or it can be said that marginal fit is a condition of the suitability of the measurement model under the fit size criteria, but it can still be continued in further analysis due to its closeness to the good fit criteria. Therefore, the model is still acceptable [28]. Based on these results, it can be concluded that this research model meets the size of the model suitability (goodness of fit) and can be continued in further analysis, that is testing the hypothesis. The estimated value of the path coefficient is known in Standardized Regression Weights while the significance of the effect is known from the value of C.R or the value of probability (p). If the value of $C R>1.96$ or $p<0.05$, then the effects of variables can be implied to be significant. The results of the overall hypothesis test are presented in Table 2 as follows.

$\mathrm{Y}_{3}=0,457 \mathrm{Y}_{1}+0,507 \mathrm{Y}_{2}+\varsigma_{3}$

$\mathrm{R}^{2}=0,777(2)$

The coefficient determination value or $\mathrm{R}$ square (R2) in SEM analysis is known as the value of square multiple correlation. This value can be explained as follows: 
- The value of squared multiple correlation in the first equation is 0.360 . This value indicates that $36.0 \%$ of the variation in the value of Destination Innovativeness is determined by the variation in the value of the Destination Knowledge variable.

- The value of squared multiple correlation in the second equation is 0.450 . This value describes that $45.0 \%$ of the variation in the value of Crowd working is determined by variations in the value of the Destination Innovativeness variable.

- The value of squared multiple correlation in the third equation is 0.777 . This value means that $77.7 \%$ of the variation in the value of Crowd working of Sustainability marketing performance is determined by variations in the value of the Destination Innovativeness and Crowd working variables.

Based on the results of SEM analysis, it can be seen that Destination Knowledge has a positive and significant effect on Destination Innovativeness. It is justified by the value of the critical ratio (CR) of which is 4,222 with a probability of 0,000 . Due to the probability value is equal to $<0.05$, it can be concluded that Destination Knowledge has a significant effect on Destination Innovativeness which means that the better the Test Knowledge is, the higher the Destination Innovativeness will increase. Hence, the first hypothesis which states that there is an influence of Destination Knowledge on Crowd working can be accepted.

In addition, based on the SEM analysis results, we can see that Destination Innovativeness has positive and significant effect on Crowd working. This is affirmed from the CR value of 4,115 with a probability of 0,000 . Since the probability value is equal to $0.05(<0.05)$, it can be inferred that Destination Innovativeness has a positive and significant effect on Crowd working. That is, the better the Destination Innovativeness is, the higher the Crowd working process will increase. Therefore, the second hypothesis which states that there is an influence of Destination Innovation on Crowd working can be accepted.

Furthermore, Job satisfaction has a positive and significant impact on Sustainability marketing performance. This is convinced from the $\mathrm{CR}$ value of 2.663 with a probability of 0.008 . Since the probability value is equal to $<0.05$, it can be concluded that Destination Innovation has a positive and significant effect on Sustainability marketing performance which means the better the Destination Innovativeness is, the higher the Sustainability marketing performance will increase. Thus, the third hypothesis is accepted.

At last, Crowd working has also a positive and significant impact on Sustainability marketing performance. This is ascertained from the CR value of 3.223 with a probability of 0.001 . Due to the probability value is equal to $<0.05$, it can be concluded that Crowd working has a positive and significant effect on Sustainability marketing performance. It means that the higher the Crowd working is, the higher the Sustainability marketing performance will increase. Thus the fourth hypothesis which says that Crowd working has effect on Sustainability marketing performance is accepted.

\section{DISCUSSION}

With social media, the opportunities to promote the tourism destination are virtually endless. Crowd working in tourism industry defines as tourism destination that employ digital natives to tagging photographs and review their experience in visiting destination to their social media with tagging accounts, hashtag, communities and people. This exploratory research is examining crowd working as a new term in tourism that has not been investigated clearly and there is not much information available on it. The purpose of conducting this research is to develop more understanding about crowd working and provide answers to how crowdfunding benefit for tourism industry.

The result show that Crowd working and knowledge destination create an engagements of destination innovativeness to promote the destination trough social media content and this holds an enormous potential for the tourism industry. The more like and subscribe they got means their content has been viewed by a lot of people, and this means the information about tourist destinations in their content has been widespread and will have an impact on increasing the number of tourist visits. The good review noticed by netizen will make good reputation of the destination and will lead to intention tourist to visit. This paper has shown the importance of crowd working and how it can transform the value chain of tourism organizations into a challenge so people work in tourism sector can develop it into an innovative strategy to reach higher marketing impact. We are aware that this is an exploratory study and that these transformations need further consideration. Therefore, future research should test the theoretical topics examined on a larger tourism sector.

Knowledge destination is an amount or information own by a tourism destination resources about the destination. People who have good knowledge destination are having much information about the destination, able to guide visitor to enjoy the destination, know about the destination well and can deliver a story about the history about the destination, have the information needed by the visitor and able to explain the amenities to the visitor.

By having good destination knowledge, the manager will be able to provide good service to visitors, and to quickly identify the changes which occur in tourist destinations and to quickly cope as well as to bring the destination in following the development of a very dynamic tourism trend. By having sufficient knowledge about tourist destinations, the power of innovation can be increased as well. Thus, the impact on marketing performance of tourism destinations will increase.

The power of innovation in a tourist destination greatly supports tourism marketing. Visitors always want to get new experiences and new stories in visiting a tourist destination. The ability of destinations to innovate in line with changes in existing tourist interests is needed to determine the marketing strategies of tourist destinations.

\section{CONTRIBUTIONS AND IMPLICATIONS}

Providing better insight about the factors which have potentials to affect Sustainability marketing performance through Destination Innovativeness in priority tourist attractions in Central Java is highly important. In improving the marketing performance of tourism destinations, a tourism destination management does not rely on human and natural 
resources only. If the condition of a tourist destination is stagnant without any significant changes, visitors will never repeat the visit and will not give a good review of their visit to the tourist destination. This is very essential since our society is far more trusting the testimony of people who have already visited a particular tourist destination. In other word, the Word of Mouth to determine travel destinations is exceptionally important.

In improving the marketing performance, the tourist destinations can be improved through the role of crowd working with its indicators such as digital communities, social media promotion and networking. Through the role of ownership of knowledge destinations and innovativeness, this research is expected to provide benefits for the development of science, especially the management knowledge in understanding the characteristics of individuals in sharing knowledge, as a reference to determine strategic plans for the development of sustainable tourism in Central Java and a reference for other researchers who will take similar themes.

\section{DIRECTION FOR FUTURE RESEARCH}

This research has not considered the heritage factor which possibly increases competitiveness / innovativeness in achieving sustainable marketing performance. The inclusion of heritage factor for further study can be a consideration.

\section{CONCLUSION}

The existing literature on the crowdsourcing concept is relatively limited. Accordingly, this research adds a novel contribution to crowdsourcing literature and evaluates it and its impact as a source of the transformation of the tourism marketing. This article proposed sustainable marketing performance through innovativeness, knowledge implication [13] and crowd working.

\section{REFERENCES}

[1] W.B. Arfi and L. Hikkerova, "External knowledge sources, green innovation and performance," Technological Forecasting and Social Change, vol. 129, pp. 210-220, 2018.

[2] J. Hoppmann and A. Sakhel, "With a little help from a stranger: The impact of external change agents on corporate sustainability investments," Business Strategy and the Environment, vol. 27, no. 7 , pp. 1052-1066, 2018.

[3] J. Fischer and M. Riechers, "A leverage points perspective on sustainability," People and Nature, vol. 1, no. 1, pp. 115-120, 2019

[4] H. Moon and W. Ruona, "Towards a deeper understanding of strategic learning," Leadership \& Organization Development Journal, vol. 36, no. 6, pp. 657-674, 2015.

[5] X. Jin and J. Wang, "Knowledge source strategy and enterprise innovation performance: dynamic analysis based on machine learning," Technology Analysis \& Strategic Management, vol. 30, no. 1, pp. 71-83, 2017.

[6] D.Z. Jovicic, "From the traditional understanding of tourism destination to the smart tourism destination," Current Issues in Tourism, vol. 22, no. 3, pp. 276-282, 2019.

[7] E. Maltz, H.H. Bi, and M. Bateman, "Benchmarking sustainability performance: the next step in building sustainable business models," Journal of Public Affairs, vol. 18, no. 3, pp. e1606, 2018
[8] M.A. Cusumano and S.J. Kahl, "Services, industry evolution, and the competitive strategies of product firms," Strategic Management Journal, vol. 36, no. 4, pp. 559-575, 2015.

[9] H.E. Lee, "Does a server's attentiveness matter? Understanding intercultural service encounters in restaurants," International Journal of Hospitality Management, vol. 50, pp. 134-144, 2015.

[10] M.A. Iniesta-Bonillo and R. Sánchez-Fernández, "Sustainability, value, and satisfaction: Model testing and cross-validation in tourist destinations," Journal of Business Research, vol. 69, no. 11, pp. 5002 5007, 2016.

[11] A.B. Ozturk and M. van Niekerk, "Volume or value: A policy decision for Turkey's tourism industry," Journal of Destination Marketing \& Management, vol. 3, no. 4, pp. 193-197, 2014.

[12] S. Heil and T. Bornemann, "Creating shareholder value via collaborative innovation: the role of industry and resource alignment in knowledge exploration," R\&D Management, vol. 48, no. 4, pp. 394-409, 2018.

[13] F.J. Zach and T.L. Hill, "Network, knowledge and relationship impacts on innovation in tourism destinations," Tourism Management, vol. 62, pp. 196-207, 2017.

[14] A. Királová, "Sustainable Tourism Marketing Strategy: Competitive Advantage of Destination," Sustainable Tourism: Breakthroughs in Research and Practice. IGI Global, pp. 183-206, 2019.

[15] M. Kobayashi, "Relational View," Annals of Business Administrative Science, vol. 13, no. 2, pp. 77-90, 2014.

[16] A. Musetescu, "How to Achieve a Competitive Advantage," Knowledge Horizons. Economics, vol. 5, no. 1, pp. 5, 2013.

[17] F. Jorge, M.S. Teixeira, R.J. Correia, R. Gonçalves, J. Martins, and M Bessa, "A Conceptual Research Model Proposal of Digital Marketing Adoption and Impact on Low Density Tourism Regions," In World Conference on Information Systems and Technologies, pp. 528-537. Springer, Cham, 2018.

[18] P. Hanna, X. Font, C. Scarles, C. Weeden, and C. Harrison, "Tourist destination marketing: From sustainability myopia to memorable experiences," Journal of Destination Marketing \& Management, vol. 9, pp. 36-43, 2018.

[19] J.K. Fatima, "Role of innovativeness and self-efficacy in tourism mlearning," Tourism Review, vol. 72, no. 3, pp. 344-355, 2017.

[20] A. Kallmuenzer and M. Peters, "Innovativeness and control mechanisms in tourism and hospitality family firms: A comparative study," International Journal of Hospitality Management, vol. 70, pp. 66-74, 2018.

[21] A.M. Hjalager, "A review of innovation research in tourism," Tourism Management, vol. 31, no. 1, pp. 1-12, 2010.

[22] J.A. Martínez-Román, "Innovativeness and business performances in tourism SMEs," Annals of Tourism Research, vvol. 54, pp. 118-135, 2015.

[23] D.E. Santini, W.J.L. Fernando, and C.F. Sampaio, "Tourists' perceived value and destination revisit intentions: The moderating effect of domain-specific innovativeness," International Journal of Tourism Research, vol. 20, no. 3, pp. 277-285, 2015.

[24] P.D.D. Thu, P. Paillé, and N. Halilem, "Systematic review on environmental innovativeness: A knowledge-based resource view," Journal of Cleaner Production, vol. 211, pp. 1088-1099, 2018.

[25] O. Adeola and O. Evans, "Digital tourism: mobile phones, internet and tourism in Africa," Tourism Recreation Research, vol. 44, no. 2, pp. 190-202, 2019.

[26] U. Sekaran and R. Bougie, Research Methods For Business, A Skill Building Approach. New York: John Willey \& Sons. Inc, 2003.

[27] J.F. Hair, W.C. Black, B.J. Babin, R.E. Anderson, and R.L. Tatham, Multivariate data analysis. Upper Saddle River, NJ: Prentice hall, vol. 5, no. 3, pp. 207-219, 1998.

[28] N. Limakrisna and S.A. Mardo, "Determinan dari nilai pelayanan dan citra institusi sistem nsw di Indonesia," MIX: Jurnal Ilmiah Manajemen, vol. 6, no. 1, pp. 154958, 2016. 